\title{
Understanding Vertical Holiness as a Received Business on Underpass Development
}

\author{
I Made Sastra Wibawa ${ }^{1}$; I Wayan Redana ${ }^{2}$ Putu Alit Suthanaya ${ }^{3}$; Ngakan Made Anom Wiryasa ${ }^{4}$. \\ ${ }^{1}$ Civil Engineering, Mahasaraswati University Denpasar, Denpasar, Indonesia \\ ${ }^{2}$ Doctoral Program in Engineering, Udayana University, Denpasar, Indonesia \\ ${ }^{3}$ Doctoral Program in Engineering, Udayana University, Denpasar, Indonesia \\ ${ }^{4}$ Doctoral Engineering Program, Udayana University, Denpasar, Indonesia \\ *e-mail: sastrawibawa@gmail.com
}

\begin{abstract}
Development efforts in the vertical direction should have been better than in the horizontal direction which only requires land to the side. The emergence of new ideas certainly raises the pros and cons, most local geniuses are vertical purity, the compilation passes under the terraced infrastructure there is a feeling of flare/fatigue because it is bypassed by people. The aim of the study is to reveal the vertical relationship with the design of underpasses, and how community acceptance of underpass construction. The methodology used is complicated through interviews with Hindu scholars, Bali, which are then used as a basis for further observation for shareholders so that questionnaires can be prepared. The results of the questionnaire are data of the relationship between vertical and attitude of community acceptance towards underpass development. The data obtained were analyzed by Logistic Regression. The results of the study of vertical simplicity are local wisdoms that need to be discussed and agreed in this modern era. Furthermore, the results of the analysis show that there is a relationship between vertical purity and uneven plot intersection height, as evidenced by the acceptance of the hypothesis at the significance level $\alpha=0.05$. The results of the analysis show "significance $<\alpha$ " or $(0.033<0.05)$, this means vertical purity, which means significant effect on underpass height design. Alternative designs also need to reduce underpass differences. Invitations are made very necessary as a legal umbrella for the design and manufacture of underpasses.
\end{abstract}

Index Terms - Alternative design, Cemer/leteh, Underpass, Vertical purity.

\section{INTRODUCTION}

$\mathrm{P}$ ros and cons still adorn the underpass construction in Bali, this is caused by the perception of some people if passing underpasses will feel shady. The emergence of this feeling is due to a passing across at the top so that it feels bypassed, or because mesulub will cause flare/fatigue. This problem must be immediately sought a solution because the construction of underpasses at some intersections seems inevitable, especially to overcome congestion. The negative impact caused in making decisions should be reduced to a minimum.

A fierce rejection happened when the plan to build the Simpang Dewa Ruci Underpass, especially the reasons stated about the passage of the community procession with a religious procession. Communities that will pass by pratima procession is unlikely to pass through mesulub at the underpass. A more in-depth study was conducted by the government and relevant stakeholders, especially the reasons for the construction of underpasses not only to overcome congestion but also to save pedestrians who want to cross. Dewa Ruci's intersection which was also known as Simpang Siur is indeed very difficult for pedestrians if they want to cross. After the underpass was built the pedestrians felt a little freedom in crossing. Moreover Sagat pedestrians need to be made special infrastructure to be able to reduce accidents, especially when crossing [1]. While the accompaniment of religious ceremonies with various devices such as pratima made an alternative route but a little twisting that is important is not mesulub.

The emergence of feeling fatigued/scattered during mesulub is the result of the concept of vertical height restrictions that have not yet been understood by the public. After conducting interviews with relevant stakeholders, it turns out that the vertical sanctity has limitations in accordance with what is stated in a number of lontar and Hindu holy books. With this concept of vertical sanctity limits, a study was conducted in the Badung community, Bali with the hope of being able to minimize the pros \& cons that occurred. Based on the background description above to direct the study, the following problem statements are proposed are, Is the community perception related to the concept of vertical purity in the high underpass design? Can the community accept the concept of vertical holiness in its role in the high underpass design?

The purpose of this study is to address general issues related to vertical purity in underpasses such as, to find out people's perceptions about understanding vertical sanctity in relation to underpass construction besides to know people's opinions about vertical sanctity in underpass construction.

\section{A. Vertical Sanctity in Spatial Scope}

Vertical sanctity is the height of the space or distance from the beachhead with the lowest elevation of 
a construction above it. When going across/mesulub in the underpass, there is doubt or feeling fatigued, then that's where the values of vertical purity become a consideration. The vertical purity limit is in accordance with what has been stated in a number of palms as a highly sanctified library in Bali that is equal to Dua Dasa Guli or twelve Guli, Lontar Purwaka Weda [2] and Lontar Surya Sewana [3]. Lontar Swamandala, said that the limit of vertical purity is One Hasta [4]. With this understanding, it is expected to be able to provide an overview and explanation of some people's doubts about crossing under the underpass or other Civil Engineering infrastructure.

As local wisdom, vertical purity is a cultural value that needs to be preserved because it originates from the religious philosophy of the cosmos imbued by Hinduism. The religious philosophy of the cosmos is believed to be able to harmonize the relationship between the psyche and the natural world of mortals through symbols, as a form of the relationship between the macro and micro nature of the cosmos. The human body as a whole is described as a microcosm of the cosmos which is distinguished from the universe as a macro cosmos [5]. These two elements are considered as different, but always exist and influence each other to form a unity (Rwa Bhineda/dualistic).

Humans as microcosmos are also called Bhuana Alit in their activities in the macro cosmos or the Bhuana Agung [6]. Both of these forms must maintain harmony to maintain harmony, the underpasses that are built should also create a sense of comfort, safety for its users, therefore the harmony and harmony of the Bhuana Agung and the Bhuana Alit must always be maintained. Underpass construction is expected to show good relations and harmony with its users.

Vertical sanctity as high as twelve Guli in accordance with what is stated in the Lontar Purwaka Weda and Lontar Surya Sewana should be understood more deeply, that purity also has a limit from the tip of our crown to as high as twelve Guli. The distance of the twelve Guli is an area that must be guarded so that its sanctity is not disturbed. one Guli according to Asta Kosala-Kosali in the concept of Development in Bali is a distance/length of the second segment of the human index finger [7], the size of the index finger used are those/residents who are considered as the head of the family. The length of the middle portion of the index finger generally ranges from two to three centimeters, if in this case an average is used then the length of one guli is two and a half centimeters, thus twelve Guli is thirty centimeter; whereas, in the Swamandala Lontar the distance of holiness is stated One Hasta. One Hasta is the length of the arm from the elbow to the tip of the finger; the average adult arm's length is forty centimeters.

\section{B. Development of Underpasses as Civil Infrastructure}

As the intersection is not a plot of underpass in Bali, its development is very slow, this is caused by the density of buildings around the intersection making it difficult to land acquisition and the feeling of fatigue/light when mesulub. Civil infrastructure is a basic physical requirement for organizing a structural system to ensure that the economy can function properly [8]. On the other hand, Civil is meant in this case is a branch of engineering that studies about how to design, build, renovate not only buildings and infrastructure, but also includes environmental sustainability.

Repairing the intersection is done by widening and subsequently by regulating the lighting/crossing lights. Previously was conducted a study on the intersection area that aims to overcome major conflicts such as collisions, vehicle maneuvering movements, and others called the Rotary Method, the result is that a sufficient amount of land is needed to improve the design of the intersection area [9] As a result of developments in various ways, congestion continues to occur, therefore an intersection with a variety of design alternatives is carried out so that the pros \& cons can be minimized.

The operation of the Trans Sarbagita Bus (Trans Denpasar, Badung, Gianyar, and Tabanan) besides being constrained by the lack of maximum facilities, especially in feeder vehicles, this also cannot solve the problem because when a traffic jam occurs, the bus is also trapped in traffic [10].

In addition to underpass the development of intersection not a plot can also be done to the top by building a flyover, the construction of the overpass is expected to overcome the existing congestion and avoid slums. Overpasses are built to avoid slums or other similar reasons, so the space under the overpass needs to be utilized so that it does not become a wasteful area. Moreover, reference [11] conducted a study under a flyover/flyover in Kuala Lumpur, Malaysia, at two different locations that were used as a place of study according to his observations that there are very large opportunities and possibilities that the space under flyover / flyover which they call the term space can be given to the surrounding community. Its use is to develop activities such as: opening cafes, food stalls, places and recreational activities, as well as business and weekly activities or activities that are not permanent. At the intersection of road traffic modeling is a very interesting field for interdisciplinary studies. The modeling carried out is based on the cellular automaton approach and observations of vehicle movements. The results are presented according to the observations of the model that one can only observe quantitative and not qualitative differences and light-controlled intersections begin to be the most efficient [12].

A study of driver behavior towards a large impact on traffic safety at a crossroads was previously conducted which studied the theme of traffic conflicts are carried out by adopting statistical methods to determine the weight of driver behavior [13]. This study shows that driving behavior that combines intersection characteristics is very helpful in explaining traffic performance at an intersection. Therefore, for a more detailed study it should also consider the behavior of the driver.

\section{Identification of underpasses}

The views of Balinese societies in general, the direction of top-down orientation; North South; holy-not holy, is guided by mountains and seas. The top, north and mountains are ascertained as holy, luan, main and the direction of the sea, south, bottom are considered to be 
unholy, teben, and despicable. Everything that is categorized as sacred and of sacred value will occupy the location at the top, north and lead to the mountain such as: the location of the temple, the direction of prayer, the direction of the head during sleep, and so on. Instead everything that is categorized as impure will occupy the location at the bottom, south and lead to the sea such as: the location of graves, animal cages, landfills / dirt, and so on [14].

The concept of development in Bali which is based on the concept of traditional space will require a fairly large land. This will give the consequences of opening new residential land so that if the new land that is opened takes green open land, then the impression of development carried out is not environmentally friendly. Moreover, later strengthened by the Provincial Government of Bali year 2009, which regulates the Regional Regulation on Spatial Planning by limiting the height of buildings as high as 15 meters or equivalent to 4 floors/level [15]. This condition is more triggering the construction of settlements and roads in the horizontal direction so that land conversion cannot be stopped.

As a result of this development, Bali and Badung in particular experienced soaring housing and land prices that were unable to be reached by the community. The government should have taken special steps to help the community to provide settlements at affordable prices for the community. Reference [16] conducted a study in Malaysia about the focus of the local government to provide housing that spread across the country so that it was affordable to all levels of society.

\section{Pros and Cons of Underpass}

In the application of technology, it will be very open in the pros and cons debates that occur [17]. Underpass development certainly cannot be separated from the application of technology; therefore this development will not be separated by the pros and cons. The difference in opinion that occurs will be widespread in debates that ultimately involve many things, even broad and broad because it involves a society that is not just a scientific community. Public debates can be categorized into three groups that have different views [17]. First, the group that has an idea that proposes the development of new infrastructure with new technology and the capital owned is quite large, usually this group is the government, investors or the private sector. Second, groups that are opposed to the group that proposes ideas, usually the reason is related to security, environmental damage due to the application of technology, or other reasons that are often associated with local wisdom. Third, a group that does not side with one or both but also cares so that the pros and cons can be suppressed and development can be continued.

Efforts to handle conflicts caused by the pros and cons of the solution can be described in five stages, namely: dispute, tension / mobilization, crisis, limited violence, and mass violence [18]. Mitigation efforts must be carried out, if unsuccessful in order to find alternatives such as choosing other infrastructure or making modifications with approaches and considerations to minimize the pros and cons.

\section{Methodology}

This study was conducted in Badung Regency, Bali, with the object of study being vertical purity associated with community acceptance as a vertical purity implementation in the high design of underpass infrastructure space. Badung already has two underpasses namely the Simpang Dewa Ruci and the Ngurah Rai Tugu intersection, besides that this area has great potential to rebuild a new underpass. Moreover, data collections conducted in this study include:

1. Direct interviews conducted with respondents, especially for stakeholders who know the issues to be studied.

2. Questionnaire (questionnaire), is a list of questions given to respondents to provide responses/answers according to questions.

The study starts with observation and examines the problem regarding people's perceptions about vertical sanctity as an implementation in his opinion across the underpass. Furthermore, library research was conducted in order to find out the theoretical concepts as well as empirical from previous studies. The study then continued by setting the study variables to be used, followed by compiling the instruments to be used/research questionnaire. Through the distribution of questionnaires obtained data, and then analyzed to make conclusions from the study.

The analytical method used in this study consisted of two approach namely:

1. Qualitative approach, which is done by conducting interviews with stake holders, especially those who are considered to understand about the values of vertical purity in spatial values. It is hoped that from this approach a theoretical study can be prepared to further be used in compiling the questionnaire.

2. Quantitative approach, which is an analysis of the relationship of people's perceptions of vertical holiness in their opinions and acceptance of the underpass. Data from filling out the questionnaire by respondents then analyzed. In this study, the Logistic Regression test is performed because the dependent variable in this study is categorical. Furtermore research in which the dependent variable is categorical is very appropriate to use the Logistic Regression test [19].

\section{RESULTS AND DISCUSSION}

Infrastructure development that involves the general public and touches on local wisdom in both design and use should be more comprehensive. Vertical purity as local wisdom is generally supported by a culture that is rooted and ingrained in Hinduism. Therefore, every step and action should follow the rules that have become a habit in society. Habits that eventually become role models in the implementation of building construction such as the height and height of the building, the position/layout of the building which is often referred to as sikut or gegulak in setting the distance and dimensions of construction used.

The various conditions of the community regarding the understanding of vertical holiness, so when collecting data through filling out the questionnaire, assistance and 
if necessary, provide an explanation of the purpose of the statements/questions in the questionnaire. Assistance is very important so there is no mistake in interpreting the intent of the statement which can ultimately give incorrect information. Accuracy and patience are needed in this activity so that the data obtained are pure and accurate. Provide an explanation of the contents of the questionnaire, but does not intervene in the answers to be given.

\section{A. Validity Test}

To find out whether an instrument is valid or not, a validity test must be carried out; in addition, a questionnaire that meets the validity test indicates whether or not to use it further [20]. This validity test shows the accuracy of the data that actually occurs on the object with the data reported by the researchers according to the results of the respondents. Decision making whether the question/statement items in the questionnaire are valid or not is based on the total value of Pearson Correlation for each question item shows a value above 0.30 . Thus the instrument can also be declared valid if the level of significance is less than 0.05 [19].

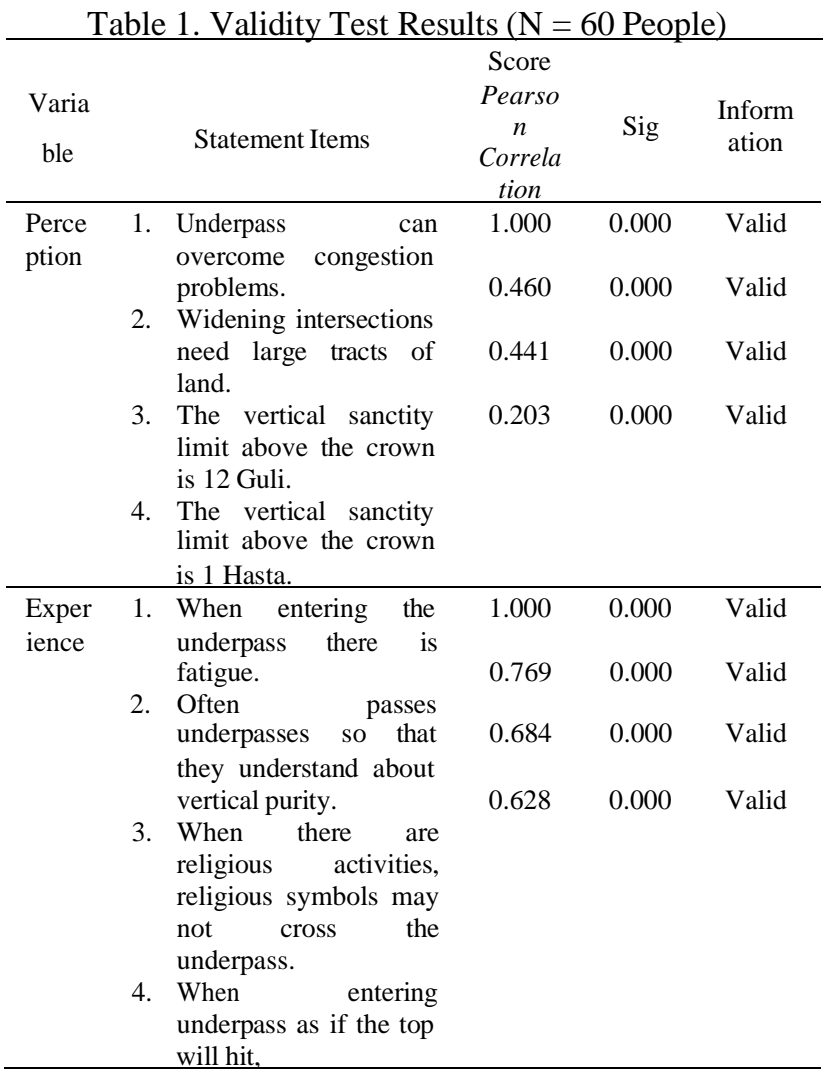

Table 1, shows that the Validity Test Results in accordance with the Pearson Correlation values obtained for all questions items obtained an average of greater than 0.3 and the results of the significance of all question items are below 0.5 . Tests conducted in accordance with the table above shows that the question items listed in the questionnaire can be used to measure perception variables and experience variables and are declared valid.

\section{B. Reliability Test}

Reliability test is very important to be carried out on research instruments because this test is a tool to measure indicators of variables or constructs. Relevant data is reliable data, usually reliable data is certainly likely to be valid [20]. A research instrument is said to be reliable if it has a Cronbach's Alpha value of greater than 0.70 .

Tabel 2. Hasil Uji Releabilitas

\begin{tabular}{|c|c|c|}
\hline Variabel & $\begin{array}{c}\text { Nilai Cronbach } \\
\text { Alpha }\end{array}$ & Keterangan \\
\hline Persepsi & 0.740 & Releabel \\
\hline Pengalaman & 0.865 & Releabel \\
\hline
\end{tabular}

In accordance with the results of the reliability test as shown in table 2, based on the results of the analysis of all variables, the Cronbach's Alpha value is greater than 0.70. Thus, it can be concluded that the instruments in this study are reliable.

\section{Logistics Regression}

1. Assess the Feasibility of the Regression Model

Through a good model good data can also be obtained, therefore the feasibility of the regression model is very important to test, then the data obtained can be analyzed because through the model data can be obtained for further analysis, here is a picture of the model used in this analysis.

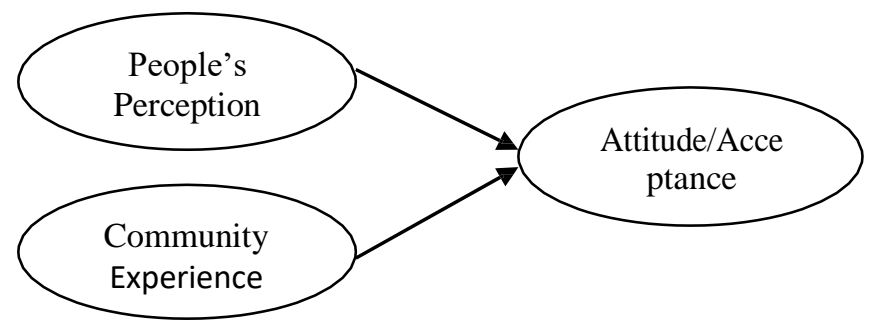

Figure 4.1 Regression Model

The feasibility test of the regression model was assessed using Hosmer and Lemeshow's Goodness of Fit Test. This test tests the null hypothesis that empirical data matches or fits the model (there is no difference between the model and the data so the model can be said to be fit). If the statistical value of Hosmer and Lemeshow's Goodness of Fit Test is equal to or less than 0.05, it means that there is a significant difference between the model and its observation value so that the Goodness of Fit model is not good because the model cannot predict the value of the observation. Likewise, if the statistical value of Hosmer and Lemeshow's Goodness of Fit Test is greater than 0.05 , then the null hypothesis is accepted and means that the model is able to predict its observational value or the model can be said to be acceptable because it matches the observational data [19].

Table 3. Hosmer and Lemeshow's Test Results

\begin{tabular}{|c|c|c|c|}
\hline Step & Chi-Squqre & Df & Sig \\
\hline 1 & 3.024 & 2 & 0.220 \\
\hline
\end{tabular}


Goodness of Fit Test is 0.220 , which is greater than 0.05 . This shows that the model is able to predict the value of its observations or it can be said the model is acceptable because it is in accordance with the observational data.

\section{Assess the Entire Model}

The overall model fit is a statistical test to determine whether all independent variables in logistic regression simultaneously influence the dependent variable [19]. Testing is done by comparing the value of $-2 \log$ Likelihood $(-2 \mathrm{LL})$ at the beginning $($ Block Number $=0$ ) with the value of $-2 \log$ Likelihood (-2LL) at the beginning (Block Number $=1$ ). The reduction in value between the initial $2 \mathrm{LL}$ and 2 final LL indicates that the hypothesized model is fit with the data.

Table 4. -2 Log Likelihood Values (-2LL)

\begin{tabular}{lc}
\hline-2 Log Likelihood & Value \\
\hline Block Number $=0$ & 67.480 \\
Block Number $=1$ & 46.930 \\
\hline
\end{tabular}

Based on the analysis results as shown in Table 4, the value of -2 Log Likelihood (-2LL) at the beginning (Block Number $=0$ ) is 67.480 which is greater than the value of -2 Log Likelihood (-2LL) at -2 Log Likelihood ($2 \mathrm{LL})$ ) at the beginning (Block Number $=1$ ) that is equal to 46.930. This means that the hypothesized model is fit with the data.

\section{Coefficient of Determination}

The coefficient of determination $\left(\mathrm{R}^{2}\right)$ basically measures how far the model's ability to explain the variation of the dependent variable. The coefficient of determination is between zero and one. A small $\mathrm{R}^{2}$ value means that the ability of the independent variables to explain the variation of the dependent variable is very limited. A value close to one means that the independent variables provide almost all the information needed to predict the dependent variable [19]. The magnitude of the coefficient of determination in the logistic regression model is indicated by the value of Nagelkerke R Square. Nagelkerke R Square value indicates the variability of the dependent variable that can be explained by the variability of the independent variable. The following table shows the results of the model's ability to explain dependent variable variations.

Table 5. Nagelkerke R Square Values

\section{Model Summary}

\begin{tabular}{|l|r|c|c|}
\hline Step & $\begin{array}{c}-2 \text { Log } \\
\text { likelihood }\end{array}$ & $\begin{array}{c}\text { Cox \& Snell } \\
\text { R Square }\end{array}$ & $\begin{array}{l}\text { Nagelkerke } \\
\text { R Square }\end{array}$ \\
\hline 1 & $46,930^{\circ}$ & .290 & .429 \\
\hline
\end{tabular}

a. Estimation terminated at iteration number 4 because parameter estimates changed by less than .001 .
Based on the results of the analysis as in Table 5, the Nagelkerke R Square value of 0.429 was obtained. This means that 42.9 percent of the variation of the variable of community acceptance of the construction of the underpass in Badung is able to be explained by people's perceptions about vertical sanctity and the community's experience of passing underpasses. The remaining 57.1 percent is explained by other factors outside the research model.

\section{Multicollinearity Test}

The purpose of the Multicollinearity Test is to test whether the regression model found a correlation between independent variables. A good regression model should not occur correlation between independent variables. Multicollinearity testing in logistic regression uses a correlation matrix between independent variables. If the correlation coefficient between independent variables is smaller than 0.8 , it means that there are no symptoms of serious multicollinearity between these independent variables [19]. Below is a correlation matrix table between independent variables.

Table 6. Correlation Matrix Value

\begin{tabular}{|ll|r|r|r|}
\multicolumn{6}{|c|}{ Corre lation Matrix } \\
\hline & & Constant & Persepsi & Pengalaman \\
\hline Step & Constant & 1.000 & -.736 & -.529 \\
1 & Persepsi & -.736 & 1.000 & .041 \\
& Pengalaman & -.529 & .041 & 1.000 \\
\hline
\end{tabular}

In accordance with the correlation matrix values shown in Table 6 , it can be explained that the correlation of all independent variables does not exceed 0.8 , this means that in the research model there is no correlation between the independent variables or the model is free from multicollinearity symptoms.

\section{Logistic Regression Model}

The logistic regression model that was formed produced a regression coefficient and significance. The regression coefficient of each variable tested shows the form of the relationship between variables. Hypothesis testing is done by comparing the significance value with the error level $(\alpha)$ if the significance $<\alpha$, it can be said that the independent variable has a significant effect on the dependent variable. Here is a logistic regression table that shows the coefficient and significance between variables.

Table 7 Results of Logistic Regression

Variables in the Equation

\begin{tabular}{|ll|r|r|r|r|r|r|}
\hline & & \multicolumn{1}{c|}{ B } & \multicolumn{1}{c|}{ S.E. } & \multicolumn{1}{c|}{ Wald } & \multicolumn{1}{c|}{ df } & \multicolumn{1}{c|}{ Sig. } & \multicolumn{1}{|c|}{$\operatorname{Exp}(\mathrm{B})$} \\
\hline S $_{1}$ tep & Persepsi & 2.115 & .819 & 6.662 & 1 & .010 & 8.286 \\
& Pengalaman & 2.093 & .747 & 7.847 & 1 & .005 & 8.107 \\
& Constant & -1.731 & .812 & 4.544 & 1 & .033 & .177 \\
\hline
\end{tabular}

a. Variable(s) entered on step 1: Persepsi, Pengalaman. 
In this study, it was tested by looking at the effect of changing people's perceptions about vertical sanctity and people's experiences crossing the underpass towards community acceptance of underpass construction in Badung, Bali. In accordance with the results of the logistic regression analysis as in Table 7, the logistic regression model in this study is:

Ln (Reception / 1-Reception) $=-1,731+2,115$ Perception +2,093 Experience

\section{Information:}

Acceptance: community acceptance of underpass construction

Perception: people's perception of vertical purity

Experience: community experience comes across the underpass

Based on the description of the perceptions and experiences of the people entering the underpass that there is acceptance of the existence of the concept of vertical purity in the construction of this underpass in accordance with the results of the analysis which shows a significance smaller than alpha $(\alpha=0.05)$. Therefore, vertical holiness values should be included in the underpass construction design. The important thing to note is to design the height of the space between the underpass elevation and the road above it, so as to add the height of the vertical purity to the vertical distance between the underpass and the road above it. With such a design, there is no longer any sense of excitement/fatigue, so there is no awkwardness to cross the underpass.

The application of vertical purity does have an element of feeling in it, therefore, if the feeling does not want to enter the mesulub into the underpass due to the feeling of flare / fatigue, then there should not be coercion. To overcome this, an alternative route was made, so that when crossing the underpass there was no need for mesulub so that no one stepped on the end there was no longer feeling fatigue/cemer.

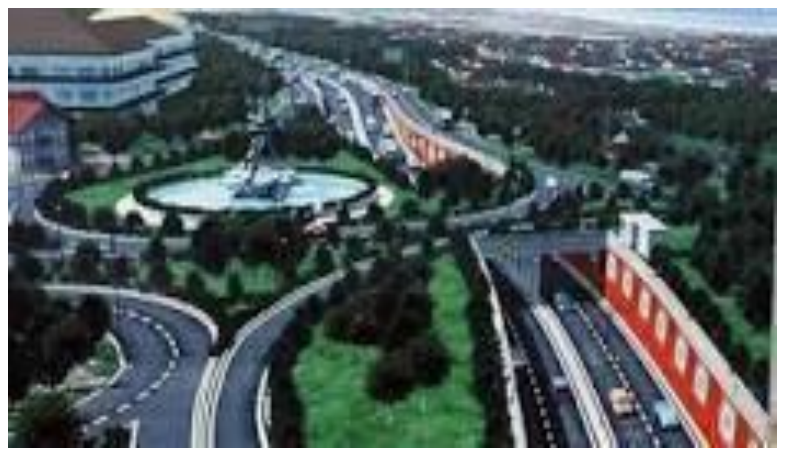

Figure 4.1. Alternative Pathway of the Dewa Ruci Intersection

At the Ngurah Rai Tugu Simpang Underpass with a height of $5.2 \mathrm{M}$, it is actually quite sufficient from the existing vertical sanctity limits. Therefore, Balinese society feel lightness/lethargy if they do mesulub under this underpass, but the alternative routes are still provided for those who are still hesitant to enter the underpass.

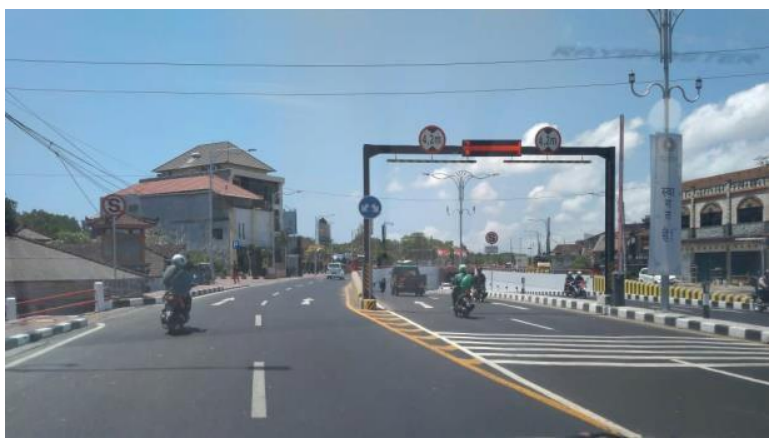

Figure 4.2. The entrance to the Ngurah Rai Tugu Underpass from Denpasar

Intersectionat the Ngurah Rai Tugu Simpang underpass because it has a fairly large crossing area, then for this underpass is also prepared for those who are not pleased to pass through the machine at the underpass especially the pratima procession, then prepare an alternative path on the left (side) of the underpass lane then slightly rotate at the roundabout and finally directly to the Nusa Dua location or direction to Denpasar.

\section{CONCLUSION}

In accordance with the results of research and analysis as well as the discussion conducted, it can be concluded that the variable community perception of vertical sanctity and community experience through the underpass has a positive effect on community acceptance of underpass construction in Badung. This is evident from the results of the analysis test significance $=0.033$ smaller than $\alpha=0.05$. With this positive influence, the answer to the existing problem is that the community accepts the concept of vertical purity in underpass construction. Therefore, making underpasses should consider the values of vertical purity in its design.

In this study do not consider events and other things that have consequences for the acceptance of the concept of underpass construction, for example someone's profession in the community as a pinandita/sulinggih, special or general building functions, or other problems that are likely to affect the acceptance or rejection of underpass buildings. Therefore, the next research is expected to consider these variables. In this study shows that vertical purity has a positive effect on the underpass building, therefore it can be suggested that if you want to build an underpass you should include the values of vertical purity in the design/plan. Surely it would be better if this could be contained in the rules/legislation regarding the height of the building/underpass so that there are rules that can be used as guidelines in planning.

\section{REFRENCES}

[1] Rankavat, S., \& Tiwari, G. (2016). Pedestrians risk perception of traffic crash and built environment featuresDelhi, India. Safety science, 87, 1-7

[2] Budayoga-a, tt, Lontar Purwaka Weda, Milik dari Drs. I.B. Gede Budayoga, M.Si ; Grya Basang Tamiang, Kapal, Mengwi, Badung, Bali.

[3] Budayoga-b, tt, Lontar Surya Sewana, Milik dari Drs. I.B. Gede Budayoga, M.Si ; Grya Basang Tamiang, Kapal, Mengwi, Badung, Bali. 
[4] Tinglis. K, tt, Lontar Swamandala, Milik dari Jro mangku Ketut Tinglis ; Pemangku Gede Pura Desa, Desa Adat Abianbase, Mengwi, Badung.

[5] Puja, 1978, Pelaksanaan P4 Bagi Umat Hindu Dharma, Jakarta, Dirjen Bimas Hindu dan Budha, Departemen Agama.

[6] Ardana, 1982, Agama Hindu dan Lingkungan Hidup, Denpasar, Proyek Seminar Kesatuan Tafsir Terhadap Aspekaspek Agama Hindu.

[7] Saraswati. AAA. O, 2002, Pamesuan Edisi ke-2, Cetakan ke2, Jimbaran-Bali, Penerbit Universitas Udayana.

[8] Sullivan Dan Arthur, 2003, Economics: Principles in Action, Upper Saddle River, New Jersey 07458: Pearson Prentice Hall. (474), ISBN 0-13-063085-3.

[9] Mahajan, S. K., Umadekar, A., \& Jethwa, K. (2013). New concept of traffic rotary design at road intersections. Procedia-Social and Behavioral Sciences, 96, 2791-2799.

[10] Sukarelawan. E, 2018, Kemacetan Lalu-lintas Acuan Pariwisata Bali, kabar24.bisnis.com diakses 11 Pebruari 2018.

[11] Qamaruz-Zaman, N., Samadi, Z., \& Azhari, N. F. N. (2012). Opportunity in leftover spaces: activities under the flyovers of Kuala Lumpur. Procedia-Social and Behavioral Sciences, 68, 451-463.

[12] Gwizdala. T.M. dan Grzebielucha. S, 2010, The traffic flow trough different form of intersections, Intertational Conference on Computer Information System and Industrial Management Applications (CISIM).
[13] Xiaoqiu, F., Jinzhang, J., \& Guoqiang, Z. (2011, January). Impact of Driving Behavior on the traffic safety of Highway Intersection. In 2011 Third International Conference on Measuring Technology and Mechatronics Automation (Vol. 2, pp. 370-373). IEEE.

[14] Parimin A.P, 1986, "Fundamental Study On Spasial Formation of Island Village : Environmental Hirarchy of Sacred-Profane Concept in Bali", Unpublished Ph.D, Dissertation, Osaka University, Japan.

[15] Pemda Prov. Bali, 2009, Perda Provinsi bali No. 16 Tahun 2009 tentang : Rencana Tata Ruang Wilayah Provinsi bali Tahun 2009 - 2029, Ka. Biro Hukum \& Ham Provinsi bali, Denpasar.

[16] Kamaruzzaman, S. N., Razali, A., Zawawi, E. M. A., Basir, S. A., \& Riley, M. L. (2018). Residents' Satisfaction Towards the Indoor Environmental Quality of Re-engineered Affordable Housing Scheme in Malaysia. International Journal of Technology, 9(3), 501-512.

[17] Redana dan Suparsa, 2014, Pengantar Teknologi Berwawasan Budaya, Udayana University Press, Denpasar.

[18] Redana, 2017, Mencegah Konflik Sosial dalam Pembangunan Infrastruktur Berkelanjutan, University Network for Indonesia Infrastructure Development (UNIID 2017), Palembang, 19-20 September 2017.

[19] Ghozali, 2016, Aplikasi Analisis Multivariate dengan Program SPSS, Semarang, Badan Penerbit Universitas Diponegoro.

[20] Sugiyono, 2012. Statistika Untuk Penelitian (Cet 2000), Bandung, CV. Alfa Beta. 